ISSN 1392-3196 / e-ISSN 2335-8947

Zemdirbyste-Agriculture, vol. 105, No. 3 (2018), p. 203-210

DOI 10.13080/z-a.2018.105.026

\title{
Effect of coapplication of poultry litter biochar and mineral fertilisers on soil quality and crop yield
}

\author{
Monika MIERZWA-HERSZTEK ${ }^{1}$, Krzysztof GONDEK ${ }^{1}$, \\ Agnieszka KLIMKOWICZ-PAWLAS ${ }^{2}$, Michał KOPEĆ ${ }^{1}$, Tomáš LOŠÁK ${ }^{3}$ \\ ${ }^{1}$ University of Agriculture in Krakow \\ Mickiewicza 21, 31-120 Krakow, Poland \\ E-mail: monika6_mierzwa@wp.pl \\ ${ }^{2}$ Institute of Soil Science and Plant Cultivation - State Research Institute \\ Czartoryskich 8, 24-100 Pulawy, Poland \\ ${ }^{3}$ Mendel University in Brno \\ Zemědělská 1/1665, 61300 Brno, Czech
}

\begin{abstract}
This study evaluated the effects of poultry litter biochar application on soil quality and yield of pasture grass mixture. A micro-plot field experiment was established on an Eutric Cambisol (CM-eu) with five treatments: 1) soil without fertilisation (control), 2) mineral fertilisation (NPK), 3) NPK + poultry litter at a rate of $5 \mathrm{t} \mathrm{ha}^{-1} \mathrm{DM}$ (PL), 4) $\mathrm{NPK}+$ poultry litter biochar at a rate of $2.25 \mathrm{t} \mathrm{ha}^{-1} \mathrm{DM}$ (PLBI) and 5) NPK + poultry litter biochar at a rate of $5 \mathrm{t} \mathrm{ha}^{-1} \mathrm{DM}$ (PLBII). Given the need to create comparable conditions, the following rates of mineral fertilisers were used in the experiment: $100 \mathrm{~kg} \mathrm{ha}^{-1} \mathrm{~N}, 40 \mathrm{~kg} \mathrm{ha}^{-1} \mathrm{P}$ and $120 \mathrm{~kg} \mathrm{ha}^{-1} \mathrm{~K}$. In 2014-2016, soil samples were analysed for changes in biological and chemical properties. Annual biomass production of pasture grass mixture was determined at three harvests per year. To characterize the biological soil properties, the soil enzymatic (dehydrogenases and urease) activity was determined. The results indicated that PLBI and PLBII reduced the contents of available forms of cadmium $(\mathrm{Cd})$, lead $(\mathrm{Pb})$ and zinc $(\mathrm{Zn})$. Significant increase in dehydrogenases activity was observed in the soil with both rates of poultry litter biochar introduced. Coapplication of PLBI or PLBII with mineral fertilisers also increased the total production of biomass of pasture grass mixture compared to the NPK treatment.
\end{abstract}

Key words: biochar, biomass yield, enzymatic activity, field experiment, heavy metals, urease activity.

\section{Introduction}

Searching for new methods of rational management of soil resources and protecting soil production values, viewed in the light of the principles of sustainable development, lead to many interesting solutions aimed at maintaining and improving the soil quality (Bayabil et al., 2015). One of those solutions is the introduction into the soil of a solid residue of thermal conversion of various types of biomass - biochar. The use of biochar in agriculture is treated as a new approach to improve the agro-technical and environmental functions of soil (Břendová et al., 2015), including climate change mitigation through carbon dioxide sequestration (Lehmann et al., 2011). Additionally, soil application of biochar as a conditioner enhances soil quality physically, chemically and biologically. Biochar stabilises or even increases soil organic matter, reduces soil deterioration, retains water and nutrients, and releases them in the soil slowly improving crop yield and quality (Yavari et al., 2015).

Recent studies have shown that biochar exhibits great potential in reducing the mobility and bioavailability of organic and inorganic compounds in various environmental matrixes, such as compost, sewage sludge and soil (Yavari et al., 2015; Rinklebe et al., 2016). These changes can be attributed to biochar properties, such as: porous structure, surface functional groups, typically alkaline $\mathrm{pH}$ and cation exchange capacity (MierzwaHersztek et al., 2016). However, short-term studies of the biochar's effect on soil, conducted under laboratory conditions, do not allow a full assessment of interactions in the complex soil-climate-plant system. The literature on biochar often provides contradictory information, which results from the type of biomass used in the production of biochar, the conditions of the process, as well as soil and climate conditions (Lehmann, Joseph, 2015). Moreover, there is not much information on the long-term impact (multi-annual studies) of biochar on soil under natural environmental conditions, including the impact on the soil chemical and biological properties, as well as biomass yield.

Please use the following format when citing the article:

Mierzwa-Hersztek M., Gondek K., Klimkowicz-Pawlas A., Kopeć M., Lošák T. 2018. Effect of coapplication of poultry litter biochar and mineral fertilisers on soil quality and crop yield. Zemdirbyste-Agriculture, 105 (3): 203-210 DOI 10.13080/z-a.2018.105.026 
Soil contamination with potential toxic elements may pose a serious threat to its quality. Given the significant differences in the physical and chemical properties of biochars, a study was conducted with the aim of determining changes in the content of available (extracted with $0.01 \mathrm{M} \mathrm{CaCl}_{2}$ ) forms of $\mathrm{Cd}, \mathrm{Pb}$ and $\mathrm{Zn}$ in soil after application of poultry litter before and after thermal conversion, the influence of biochar on enzymatic activity and biomass yield depending on the rate applied.

\section{Materials and methods}

Description of organic materials. Ground poultry litter was subjected to thermal conversion at $300 \pm$ $10^{\circ} \mathrm{C}$ for 15 minutes, while maintaining the rate of heating in the combustion chamber at $10^{\circ} \mathrm{C} \mathrm{min}^{-1}$, under a limited supply of air (1-2\%). The pyrolysis time and temperature were established on the basis of results reported in literature (Al-Wabel et al., 2013; Gondek, MierzwaHersztek, 2017). Organic materials were subsequently analysed for their basic properties (Table 1).

Soil properties, experimental design and climate. The micro-plot $\left(1 \mathrm{~m}^{2}\right)$ experiment was carried out in 2014-2016 on an arable land located in southern Poland $\left(50^{\circ} 08.404^{\prime} \mathrm{N}, 19^{\circ} 85.362^{\prime} \mathrm{E}\right)$, in three replicates using the method of randomised blocks. The soil type was loamy sand Eutric Cambisol (CM-eu) according to WRB (2014) classification.

Table 1. Selected properties of poultry litter and biochar produced from it (Mierzwa-Hersztek et al., 2017)

\begin{tabular}{lccc}
\hline \multicolumn{1}{c}{ Properties } & Unit & Poultry litter (PL) & Poultry litter biochar (PLB) \\
\hline $\mathrm{pH} \mathrm{in} \mathrm{H}_{2} \mathrm{O}$ & - & $7.53 \pm 0.02$ & $8.10 \pm 0.02$ \\
\hline Electrical conductivity & $\mu \mathrm{S} \mathrm{cm}^{-1}$ & $49.1 \pm 12.4$ & $91.5 \pm 2.60$ \\
\hline Dry matter $(\mathrm{DM})$ & $\mathrm{g} \mathrm{kg}^{-1}$ & $445.0 \pm 1.00$ & $986.0 \pm 0.20$ \\
\hline Cation exchange capacity & $\mathrm{mol} \mathrm{kg}^{-1} \mathrm{DM}$ & $1.87 \pm 0.03$ & $1.92 \pm 0.02$ \\
\hline Ash & & $312.6 \pm 0.66$ & $420.5 \pm 0.43$ \\
Carbon $\left(\mathrm{C}_{\text {total }}\right)$ & $\mathrm{g} \mathrm{kg}^{-1} \mathrm{DM}$ & $323 \pm 0.30$ & $377 \pm 0.30$ \\
Nitrogen $\left(\mathrm{N}_{\text {total }}\right)$ & & $24.9 \pm 0.74$ & $26.2 \pm 1.10$ \\
Phosphorus $\left(\mathrm{P}_{\text {total }}\right)$ & & $13.2 \pm 0.36$ & $30.5 \pm 0.31$ \\
Potassium $\left(\mathrm{K}_{\text {total }}\right)$ & & $17.8 \pm 0.39$ & $37.3 \pm 2.36$ \\
\hline Cadmium $\left(\mathrm{Cd}_{\text {total }}\right)$ & & $0.39 \pm 0.01$ & $0.55 \pm 0.03$ \\
Chromium $\left(\mathrm{Cr}_{\text {total }}\right)$ & $2.82 \pm 0.31$ & $16.4 \pm 0.60$ \\
Nickel $\left(\mathrm{Ni}_{\text {total }}\right)$ & $3.42 \pm 0.14$ & $10.8 \pm 0.49$ \\
Copper $\left(\mathrm{Cu}_{\text {total }}\right)$ & $\mathrm{mg} \mathrm{kg}^{-1} \mathrm{DM}$ & $16.1 \pm 1.22$ & $57.6 \pm 0.88$ \\
Lead $\left(\mathrm{Pb}_{\text {total }}\right)$ & & $2.02 \pm 0.20$ & $3.91 \pm 0.61$ \\
Zinc $\left(\mathrm{Zn}_{\text {total }}\right)$ & & $111 \pm 5$ & $280 \pm 3$ \\
Arsenic $\left(\mathrm{As}_{\text {total }}\right)$ & & $1.54 \pm 0.07$ & $1.66 \pm 0.07$ \\
Mercury $\left(\mathrm{Hg}_{\text {total }}\right)$ & $0.068 \pm 0.004$ & $0.018 \pm 0.003$ \\
\hline Specific surface area $\left(\mathrm{S}_{\mathrm{BET}}\right)$ & $\mathrm{m}^{2} \mathrm{~g}^{-1}$ & $1.83 \pm 0.22$ & $2.76 \pm 0.29$ \\
\hline Pore volume & $\mathrm{cm}^{3} \mathrm{~g}^{-1}$ & $0.006 \pm 0.000$ & $0.011 \pm 0.002$ \\
\hline Pore diameter & $\mathrm{nm}$ & $14 \pm 2$ & $18 \pm 3$
\end{tabular}

\pm standard deviation, $\mathrm{n}=3$

The climate of the experimental site is temperatecontinental. Annual sum of precipitation was $681 \mathrm{~mm}$ in 2014, $561 \mathrm{~mm}$ in 2015 and $786 \mathrm{~mm}$ in 2016. The mean monthly air temperature during the studied period varied from $-0.9^{\circ} \mathrm{C}$ (January) to $20.1^{\circ} \mathrm{C}$ (July) in 2014 , from $-3.3^{\circ} \mathrm{C}$ (January) to $17.5^{\circ} \mathrm{C}$ (July) in 2015 and from $-2.3^{\circ} \mathrm{C}$ (January) to $19.4^{\circ} \mathrm{C}$ (July) in 2016 (Fig. 1).

The following treatments were carried out: 1) soil without fertilisation (control), 2) mineral fertilisation (NPK), 3) NPK + poultry litter at a rate of $5 \mathrm{t} \mathrm{DM} \mathrm{ha-1}$

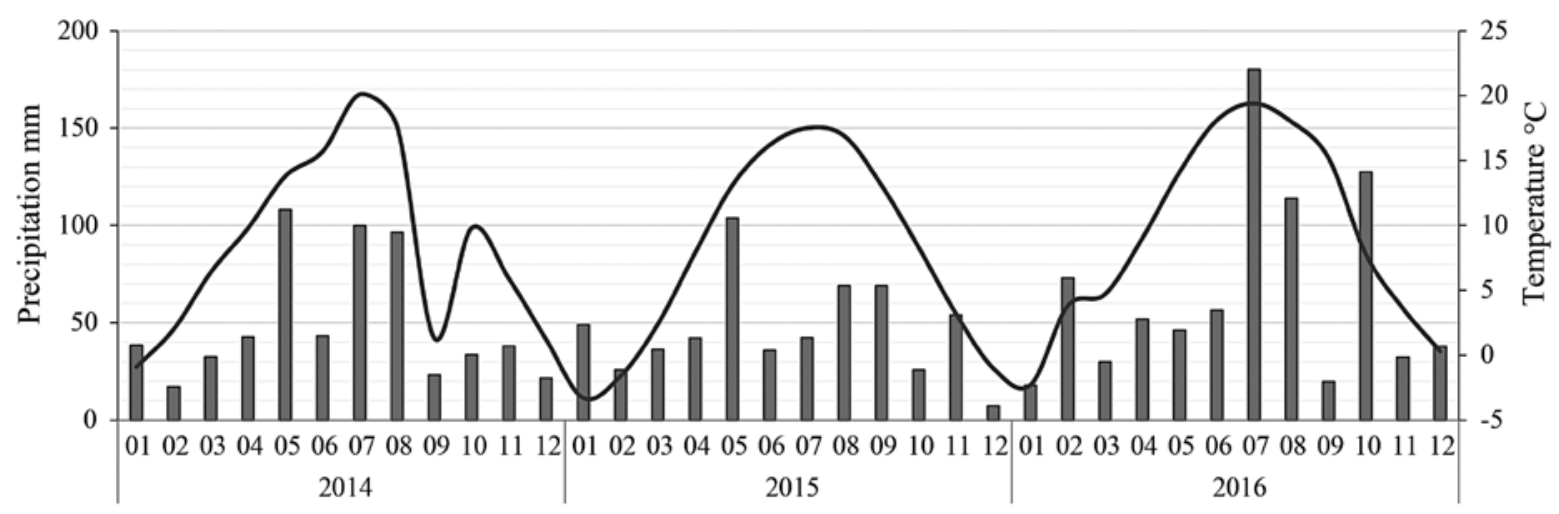

Precipitation mm

— Monthly air temperature ${ }^{\circ} \mathrm{C}$

Figure 1. Monthly mean sums of precipitation and monthly air temperature 
(PL), 4) NPK + biochar at a rate of $2.25 \mathrm{t} \mathrm{DM} \mathrm{ha}^{-1}(\mathrm{PLBI})$ and 5) NPK + biochar at a rate of $5 \mathrm{t} \mathrm{DM} \mathrm{ha}^{-1}$ (PLBII). Poultry litter and poultry litter biochar were used once in the first year of the experiment (2014) (Table 1).

Given the need to create comparable conditions, the following rates of mineral fertilisers were applied in the experiment: $100 \mathrm{~kg} \mathrm{ha}^{-1} \mathrm{~N}, 40 \mathrm{~kg} \mathrm{ha}^{-1} \mathrm{P}$ and $120 \mathrm{~kg} \mathrm{ha}^{-1}$ $\mathrm{K}$. The rate of phosphorus $(\mathrm{P})$ was applied once for the first crop in the form of enriched triple superphosphate. Potassium $(\mathrm{K})$ was added in the form of $\mathrm{K}$ salt, and nitrogen $(\mathrm{N})$ - in the form of ammonium nitrate. Assuming that three crops are to be harvested, rates of $\mathrm{P}$ and $\mathrm{N}$ were divided into three equal parts (for each crop). The same fertilisation with NPK was repeated in each year of the experiment. Poultry litter and poultry litter biochar were mixed with the topsoil $(0-10 \mathrm{~cm})$, and then, the seeds of pasture grass mixture: Phleum pratense 'Erecta' - 15\%, Festuca pratensis 'Ardeinia' - 10\%, F. arundinacea 'Alix' - 10\%, Lolium perenne 'Victorian' - 20\%, L. perenne 'Solen' - 20\%, L. multiflorum 'Gaza' - 10\%, Trifolium pratense 'Dajana' - 5\%, L. westerwoldicum 'Mowester' $-10 \%$, at a seeding rate of $60 \mathrm{~kg} \mathrm{ha}^{-1}$ were sown. Soil samples were collected from each plot $\left(1 \mathrm{~m}^{2}\right)$ from the $0-10 \mathrm{~cm}$ soil layer after the $1^{\text {st }}, 2^{\text {nd }}$ and $3^{\text {rd }}$ year (8, 18 and 30 months after the application of organic materials), after the vegetation was finished. For chemical and physicochemical analyses, soil samples were dried and passed through a sieve with apertures of $1 \mathrm{~mm}$. Enzymatic activity of the soil was determined in fresh soil samples. Annual production of pasture grass mixture biomass was determined by mechanical harvesting (three harvests per year). The above-ground biomass from each micro-plot was collected separately. Biomass was dried to constant weight at $60^{\circ} \mathrm{C}$, and dry mass was determined.

The total contents of macroelements and trace elements were determined after incineration of the sample in a chamber furnace (at $450{ }^{\circ} \mathrm{C}$ for $12 \mathrm{~h}$ ) and mineralisation of the residue in a mixture of concentrated nitric and perchloric acids $(3: 2, \mathrm{v} / \mathrm{v})$. Mercury $(\mathrm{Hg})$ was determined on an AMA 254 apparatus (LECO Corporation, USA) in which it was released from the amalgamator and measured by the atomic absorption method at a wavelength of $254 \mathrm{~nm}$. The arsenic (As) content was determined using the inductively coupled plasma mass spectrometry apparatus Agillent 7500ce ICP-MS (Perkin Elmer, USA) after the previous extraction of the sample in a microwave system (MARS XPRESS, CEM Corp.) in a mixture of concentrated acids hydrogen chloride $(\mathrm{HCl})$ and nitric acid $\left(\mathrm{HNO}_{3}\right)(3: 1, \mathrm{v} / \mathrm{v})$. The available forms of cadmium $(\mathrm{Cd})$, lead $(\mathrm{Pb})$ and zinc $(\mathrm{Zn})$ were extracted from the soil with $0.01 \mathrm{M}$ solution of calcium chloride $\left(\mathrm{CaCl}_{2}\right)$ (soil:solution $=1: 10$ ) for 2 hours (Houba et al., 2000). The content of metals (Cd, $\mathrm{Cr}, \mathrm{Ni}, \mathrm{Pb}$ and $\mathrm{Cu}$ ) was analysed by inductively coupled plasma optical emission spectroscopy (ICP-OES) using the Perkin Elmer Optima 7300 DV instrument (Perkin Elmer) (Oleszczuk et al., 2007).

Dehydrogenases activity was determined according to Thalmann's (1968) method, using triphenyltetrazolium chloride (TTC) as the electron acceptor. Samples were incubated at $37 \pm 2{ }^{\circ} \mathrm{C}$ for 24 hours. Triphenylformazan (TPF) resulting from the reduction of TTC in soil was extracted with acetone, and the intensity of the solution red colour was measured. Urease activity was determined by the Zantua and Bremner (1975) method, with urea as a substrate, after 18-hours incubation at $37 \pm 2{ }^{\circ} \mathrm{C}$. The final results were expressed as an arithmetic mean of three replicates. Activity of dehydrogenases and urease was determined by colourimetry using a Backman DU 640 spectrophotometer (Backman, USA) at the wavelength of 485 and $470 \mathrm{~nm}$, respectively.

Statistical analysis. All statistical analyses were performed using software Statistica PL, version 12.5 (StatSoft Inc.). Mean values were taken from each triplicate data set. The differences between each treatment and the control, as well as between treatments were evaluated using one-way analysis of variance (ANOVA), Duncan's test $(p \leq 0.05)$. Variation within treatments was determined by calculating the values of standard deviation $( \pm S D)$. Furthermore, in order to determine the diversity within the analysed population, the coefficient of variation $(\mathrm{V} \%)$ was calculated as a share of SD in the arithmetic mean of the analysed parameters.

\section{Results and discussion}

Soil and biochar element content. Poultry litter (PL) had lower values of $\mathrm{pH}$, electrical conductivity, dry matter and cation exchange capacity compared to biochar obtained from this material (Table 1). The contents of total $\mathrm{N}, \mathrm{C}, \mathrm{P}$ and $\mathrm{K}$, as well as specific surface area in poultry litter biochar (PLB) were higher than in nonpyrolised poultry litter. Poultry litter biochar had also higher content of potential toxic elements compared to poultry litter. The content of all potentially toxic elements in PLB was significantly lower than the values proposed for premium class biochars (EBC, 2017). As demonstrated by Hossain et al. (2011), the content of trace elements increases based on the temperature used during the pyrolysis process and it corresponds to the weight loss. Song and Guo (2012) suggested that, for agricultural purposes, the temperature of material pyrolysis should be approx. $300^{\circ} \mathrm{C}$. In studies carried out by Yachigo and Sato (2013), increased pyrolysis temperature resulted in the increase in the $\mathrm{Zn}$ and $\mathrm{Cu}$ contents in the obtained material, while no changes in $\mathrm{Cd}$ content were observed. According to $\mathrm{He}$ et al. (2010), the pyrolysis temperature above $350^{\circ} \mathrm{C}$ causes greater stability of such trace elements as $\mathrm{Cd}, \mathrm{Pb}, \mathrm{Zn}$ and $\mathrm{Cu}$. This results from the loss of unstable aliphatic bonds and creation of more stable aromatic bonds (Kloss et al., 2012). As stated by Hossain et al. (2011), despite the increase in the total content of potential toxic elements as a result of pyrolysis of sewage sludge, the content of bioavailable forms did not change much.

Before it had been amended with organic materials, the soil used in the experiment had slightly acidic reaction $\left(\mathrm{pH} \mathrm{H}_{2} \mathrm{O}=6.46\right)$ and natural content of heavy metals $\left(0.63,25.5\right.$ and $138 \mathrm{mg} \mathrm{kg}^{-1}$ for $\mathrm{Cd}, \mathrm{Pb}$ and $\mathrm{Zn}$, respectively) (Mierzwa-Hersztek et al., 2016). The total content of nitrogen was $1.28 \mathrm{~g} \mathrm{~kg}^{-1} \mathrm{DM}$, carbon $9.84 \mathrm{~g} \mathrm{~kg}^{-1} \mathrm{DM}$. In general, it was found that the application of poultry litter before and after thermal conversion in analysed (2014-2016) years resulted in no significant changes in soil $\mathrm{pH}$ and electrical conductivity (Table 2). Also, it caused no significant increase in the contents of $\mathrm{N}_{\text {total }}$ in soil compared to their values determined before setting up the experiment. Significant changes in total carbon content in soil were observed in all treatments with the addition of organic materials (PL, PLBI and PLBII) after the $1^{\text {st }}$ and the $2^{\text {nd }}$ year of the experiment. After the $3^{\text {rd }}$ year (2016) of the experiment, significant increase in 
Table 2. Selected soil properties (layer $0-10 \mathrm{~cm}$ )

\begin{tabular}{|c|c|c|c|c|c|}
\hline & Treatment & $\begin{array}{c}\mathrm{pH} \\
\text { in } \mathrm{H}_{2} \mathrm{O} \\
\end{array}$ & $\begin{array}{c}\text { Electrical conductivity } \\
\mu \mathrm{S} \mathrm{cm} \mathrm{cm}^{-1}\end{array}$ & $\begin{array}{c}\mathrm{C}_{\text {total }} \\
\mathrm{g} \mathrm{kg}^{-1} \mathrm{DM} \\
\end{array}$ & $\begin{array}{c}\mathrm{N}_{\text {total }} \\
\mathrm{g} \mathrm{kg}^{-1} \mathrm{DM} \\
\end{array}$ \\
\hline & Control (without fertilisation) & $6.40 \mathrm{ab}$ & $170 \mathrm{a}$ & $10.6 \mathrm{~b}$ & $1.09 \mathrm{~b}$ \\
\hline \multirow{5}{*}{2014} & Mineral fertilisation (NPK) & $6.21 \mathrm{a}$ & $153 \mathrm{a}$ & $9.45 \mathrm{a}$ & $0.96 \mathrm{a}$ \\
\hline & PL & $6.44 \mathrm{ab}$ & $220 \mathrm{a}$ & $10.8 \mathrm{~b}$ & $1.11 \mathrm{~b}$ \\
\hline & PLBI & $6.47 \mathrm{ab}$ & $227 \mathrm{a}$ & $10.7 \mathrm{~b}$ & $1.08 \mathrm{~b}$ \\
\hline & PLBII & $6.87 \mathrm{bc}$ & $513 \mathrm{~b}$ & $11.2 \mathrm{~b}$ & $1.13 \mathrm{~b}$ \\
\hline & Control & $6.75 \mathrm{a}$ & $40.7 \mathrm{a}$ & $11.4 \mathrm{~b}$ & $0.94 \mathrm{a}$ \\
\hline \multirow{5}{*}{2015} & NPK & $6.56 \mathrm{a}$ & $45.0 \mathrm{a}$ & $10.2 \mathrm{a}$ & $0.96 \mathrm{a}$ \\
\hline & PL & $6.60 \mathrm{a}$ & $46.6 \mathrm{a}$ & $11.3 \mathrm{~b}$ & $0.98 \mathrm{a}$ \\
\hline & PLBI & $6.49 \mathrm{a}$ & $37.4 \mathrm{a}$ & $10.8 \mathrm{~b}$ & $0.94 \mathrm{a}$ \\
\hline & PLBII & $6.57 \mathrm{a}$ & $48.8 \mathrm{~b}$ & $12.1 \mathrm{~b}$ & $0.97 \mathrm{a}$ \\
\hline & Control & $6.13 \mathrm{~b}$ & $92.0 \mathrm{a}$ & $11.5 \mathrm{ab}$ & $0.95 \mathrm{a}$ \\
\hline \multirow{4}{*}{2016} & NPK & $5.86 \mathrm{a}$ & $95.7 \mathrm{a}$ & $10.7 \mathrm{a}$ & $0.91 \mathrm{a}$ \\
\hline & PL & $6.04 \mathrm{ab}$ & $102 \mathrm{a}$ & $12.2 \mathrm{~b}$ & $1.06 \mathrm{a}$ \\
\hline & PLBI & $5.94 \mathrm{ab}$ & $97.7 \mathrm{a}$ & $11.8 \mathrm{ab}$ & $1.01 \mathrm{a}$ \\
\hline & PLBII & $6.03 \mathrm{ab}$ & $97.7 \mathrm{a}$ & $11.4 \mathrm{ab}$ & $1.02 \mathrm{a}$ \\
\hline
\end{tabular}

Note. PL - NPK + poultry litter at a rate of $5 \mathrm{tha}^{-1} \mathrm{DM}, \mathrm{PLBI}-\mathrm{NPK}+$ biochar at a rate of $2.25 \mathrm{tha}^{-1} \mathrm{DM}, \mathrm{PLBII}-\mathrm{NPK}+$ biochar at a rate of $5 \mathrm{tha}^{-1} \mathrm{DM}$; mean values marked with the same letters in columns do not differ significantly according to the Duncan's test at $p \leq 0.05$ (factor - fertilisation); DM - dry matter.

the carbon content was determined only in poultry litter soil. Opposite results were reported by Wang et al. (2015) who found that the application of biochar produced at a low pyrolysis temperature $\left(300^{\circ} \mathrm{C}\right)$ caused significant increase in the soil organic matter content. The authors explained that biochars produced at lower temperatures contained more of the incompletely pyrolysed fraction of the feedstock material. Furthermore, the high content of aliphatic $\mathrm{C}-\mathrm{H}$ bonds in biochars pyrolysed at lower temperature indicated more usable feedstock in biochars.

The suitability of biochar for agriculture is determined mainly by its physical and chemical properties, which are a function of feedstock and conditions of the pyrolysis process under which the biochar was produced. Increased soil $\mathrm{pH}$ following the application of biochar may markedly affect the content and mobility of heavy metals in soil. As a result of chemical and biological processes in soil, the alkaline substances are more easily released from biochars. It is especially visible for carbonates and calcium and magnesium cations, which are easily taken into the soil solution (Park et al., 2011; Yang et al., 2016). In our study, the content of analysed heavy metals in forms extracted with $0.01 \mathrm{M} \mathrm{CaCl}_{2}$ depended on the type of organic material introduced into the soil as well as type of element (Table 2). The addition of poultry litter reduced the content of available forms of $\mathrm{Cd}$ in the soil in studied years by $35 \%$, on average. Also, the addition of poultry litter biochar in both rates (PLBI and PLBII) caused a statistically significant reduction of the content of available forms of Cd (average from 3 years) by $24 \%$ and $41 \%$, respectively, compared to the control treatment. These results are consistent with the observations of Xu et al. (2014) who discovered that the content of bioavailable forms of $\mathrm{Cd}$ was significantly reduced with increased rate of pig manure biochar. Zheng et al. (2015) demonstrated that the addition of biochar produced from bean stalks and rice straw significantly reduced the availability of $\mathrm{Cd}$, which was reflected in the content of this element in rice roots, shoots, and grains. Similar observations were published by Xu et al. (2016), who in the cultivation of maize used biochars obtained from bamboo, rice straw and maize straw in order to reduce the bioavailability of $\mathrm{Cd}$.

Greater variation in the content of available forms, depending on the type of material and rate of amendment, was noted for $\mathrm{Pb}$ (Table 3). The application of $5 \mathrm{t} \mathrm{ha}^{-1} \mathrm{DM}$ of biochar (PLBII) significantly reduced the content of available $\mathrm{Pb}$ by $30 \%$ in $2014,59 \%$ in 2015 and by $14 \%$ in 2016 compared to the control treatment. The introduction of PL and PLBI in a half rate (2.25 $\left.\mathrm{tha}^{-1} \mathrm{DM}\right)$ was similar in analysed years and reduced the element content by $37 \%$ in both (PL and PLBI) cases, on average. The reduction of the available forms of $\mathrm{Pb}$ and Cd was probably due to the sorption capacity of biochar, which is closely related to the conditions under which the pyrolysis process is conducted, and the feedstock used in its production. Study results published so far have proved that, depending on its density and porosity, biochar may differently affect the environment, including bioavailability of heavy metals (Al-Wabel et al., 2013). Additionally, the reduction of available forms of $\mathrm{Cd}$ and $\mathrm{Pb}$ reported in our study was beneficial for dehydrogenases activity. The results presented by Liu et al. (2016) showed that these elements may be among the main inhibitors of dehydrogenases activity, and the decrease in soil $\mathrm{pH}$ changes the degree of oxidation of these metals and reduces their adverse effects on the enzymatic activity of soil. Studies of Zheng et al. (2015) have found that only biochar produced from rice straw reduced the availability of $\mathrm{Pb}$, but it was not reflected in the rice biomass. Similar observations were published by $\mathrm{Xu}$ et al. (2016), who showed the decrease of bioavailable forms of $\mathrm{Pb}$ and reduced accumulation of $\mathrm{Pb}$ in plant biomass.

In the case of $\mathrm{Zn}$, significant increase (compared to other treatments) in mobile $\mathrm{Zn}$ in soil was observed in all years only in the soil of PLBII (Table 2). No significant changes in the content of available forms of $\mathrm{Zn}$ were reported in the case of PL and PLBI in studied years (with the exception of PL treatment in 2015 and 2016). It should be noted that $\mathrm{Zn}$, as one of the most mobile metals in soil, tends to form unstable complexes with organic matter, from which, due to changes in $\mathrm{pH}$, it is relatively easily taken into the soil solution, and in larger concentrations may pose a threat for microorganisms and plants (Yang et al., 2016).

Dehydrogenases activity. The presence of potentially toxic substances, toxic heavy metals and polycyclic aromatic hydrocarbons (PAHs) in biochar and usually strongly alkaline $\mathrm{pH}$ may constitute a serious 
Table 3. Contents of available forms of cadmium $(\mathrm{Cd})$, lead $(\mathrm{Pb})$ and zinc $(\mathrm{Zn})$ after extraction with $0.01 \mathrm{M} \mathrm{CaCl}_{2}$ (mg kg-1 dry matter)

\begin{tabular}{|c|c|c|c|c|c|c|c|}
\hline \multirow[b]{2}{*}{ Year } & \multirow[b]{2}{*}{ Metal } & \multicolumn{5}{|c|}{ Treatment } & \multirow[b]{2}{*}{$\mathrm{CV} \%$} \\
\hline & & $\begin{array}{c}\text { control } \\
\text { (without } \\
\text { fertilisation) }\end{array}$ & $\begin{array}{c}\text { mineral } \\
\text { fertilisation } \\
(\mathrm{NPK})\end{array}$ & PL & PLBI & PLBII & \\
\hline \multirow{3}{*}{2014} & $\mathrm{Cd}$ & $0.13 \mathrm{~b}$ & $0.10 \mathrm{~b}$ & $0.07 \mathrm{a}$ & $0.07 \mathrm{a}$ & $0.04 \mathrm{a}$ & 40.5 \\
\hline & $\mathrm{Pb}$ & $0.15 \mathrm{~b}$ & $0.15 \mathrm{~b}$ & $0.09 \mathrm{a}$ & $0.09 \mathrm{a}$ & $0.10 \mathrm{a}$ & 24.8 \\
\hline & $\mathrm{Zn}$ & $2.06 \mathrm{~b}$ & $2.54 \mathrm{~b}$ & $1.83 \mathrm{~b}$ & $1.92 \mathrm{~b}$ & $0.93 \mathrm{a}$ & 36.3 \\
\hline \multirow{3}{*}{2015} & $\mathrm{Cd}$ & $0.12 \mathrm{~b}$ & $0.12 \mathrm{~b}$ & $0.07 \mathrm{a}$ & $0.10 \mathrm{a}$ & $0.07 \mathrm{a}$ & 28.4 \\
\hline & $\mathrm{Pb}$ & $0.17 \mathrm{c}$ & $0.15 \mathrm{c}$ & $0.10 \mathrm{ab}$ & $0.13 \mathrm{bc}$ & $0.07 \mathrm{a}$ & 34.7 \\
\hline & $\mathrm{Zn}$ & $2.23 \mathrm{~b}$ & $2.82 \mathrm{~b}$ & $1.80 \mathrm{ab}$ & $3.20 \mathrm{~b}$ & $1.78 \mathrm{a}$ & 35.9 \\
\hline \multirow{3}{*}{2016} & $\mathrm{Cd}$ & $0.14 \mathrm{ab}$ & $0.17 \mathrm{c}$ & $0.12 \mathrm{a}$ & $0.13 \mathrm{ab}$ & $0.11 \mathrm{a}$ & 16.7 \\
\hline & $\mathrm{Pb}$ & $0.09 \mathrm{~b}$ & $0.06 \mathrm{ab}$ & $0.06 \mathrm{ab}$ & $0.05 \mathrm{a}$ & $0.05 \mathrm{a}$ & 35.9 \\
\hline & $\mathrm{Zn}$ & $4.62 \mathrm{~b}$ & $5.55 \mathrm{c}$ & $3.68 \mathrm{a}$ & $4.72 \mathrm{bc}$ & $3.60 \mathrm{a}$ & 19.1 \\
\hline
\end{tabular}

Explanations under Table 2

threat to soil quality, and in particular, to its biological life (Yang et al., 2016). Organic and inorganic contaminants introduced into the soil with biochar can have a significant impact on the population of microorganisms (Cui et al., 2013). The present study demonstrated that both rates (2.25 and $\left.5 \mathrm{t} \mathrm{ha}^{-1} \mathrm{DM}\right)$ of biochar added to the soil had a beneficial effect on dehydrogenases activity in the $2^{\text {nd }}$ and $3^{\text {rd }}$ year of the experiment (Fig. 2). Dehydrogenases activity in PLBI treatment increased by $18 \%$ in 2015 and by $93 \%$ in 2016 compared to control treatment. The application of a double rate of biochar (PLBII) increased the dehydrogenases activity by $19 \%$ in 2015 and by $54 \%$ in 2016 compared to the control. On the other hand, the application of poultry litter significantly increased the dehydrogenases activity after the $1^{\text {st }}$ (by $18 \%$ ) and after the $3^{\text {rd }}$ (by 24\%) year of the study compared to control treatment. After the $2^{\text {nd }}$ year of the experiment, the dehydrogenases activity in the soil of PL treatment was lower than the enzyme activity in non-fertilised soil. Probably, the dehydrogenases activity was strongly influenced by the weather conditions. The lowest dehydrogenases activity in the $1^{\text {st }}$ and $3^{\text {rd }}$ year of the present study was observed in soil with mineral fertilisation (NPK), which may be the result of slightly higher concentrations of available forms of heavy metals (Table 2) and also the absence of organic matter in the soil. Generally, the increase in the dehydrogenase activity is an indication of a positive priming effect of biochar. The results also suggest that biochar may contain more labile substrates which enhance the activity of soil microorganisms. Wang et al. (2007) argued that reduced availability of heavy metals following the application of biochar increased the number of microorganisms, and thus the enzymatic activity of soil. Cui et al. (2013) also demonstrated a positive correlation between the content of bioavailable heavy metal forms, enzymatic activity and $\mathrm{pH}$ of soil.

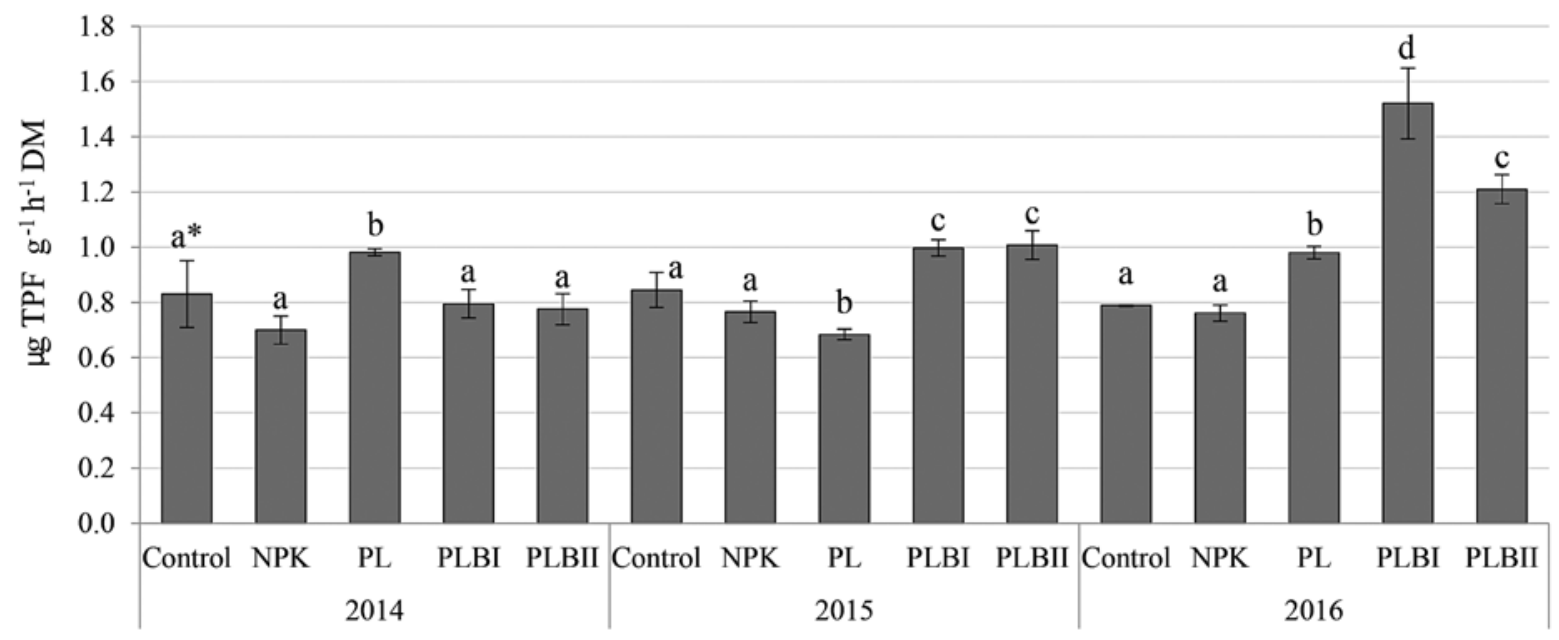

Explanations in and under Table 2; TPF - triphenylformazan

Figure 2. Dehydrogenases activity of soil in different experimental treatments

Urease activity. Many authors indicated that urease activity is valuable information on the ecological state of the soil fertilised with organic materials (Wang et al., 2015; Mierzwa-Hersztek et al., 2016). Urease activity is not only a good bioindication test for soil quality assessment, but also is most commonly used to determine the efficiency of nitrogen fertilisation (Zantua, Bremner, 1975). In the study, urease activity was influenced not only by the fertilisation applied, but also by the year of the study (Fig. 3). In 2014-2016, the lowest urease activity was determined in control treatment. Starting from the $2^{\text {nd }}$ year of the experiment, a significant $(p \leq 0.05)$ increase in urease activity was found in all treatments fertilised with organic materials (PL, PLBI and PLBII) compared to the treatment without any fertilisation. After the $1^{\text {st }}$ and $3^{\text {rd }}$ year of the study, the highest urease activity was noted 
in the soil fertilised with poultry litter and, after the $2^{\text {nd }}$ year, in the soil with the addition of $5 \mathrm{tha}^{-1} \mathrm{DM}$ of PLBII (with high variability within the treatment). However, based on the present results it is difficult to demonstrate the unambiguous effect of the applied fertilisation on the activity of these enzymes. The results obtained in this study are confirmed by the literature (Zhu et al., 2017). The quoted authors showed that soil $\mathrm{pH}$, weather conditions and the dynamics of nitrogen compounds conversion have a significant effect on urease activity.
The variable effect of biochar over timer on the activity of soil enzymes was also reported by Bailey et al. (2011). These authors demonstrated that the biochar's effect depends on the types of soil and enzyme, and that the interaction of biochar with soil can affect the function of enzymes. The ambiguity of the results obtained and contradictory literature data indicate the need for longtime studies in order to identify mechanisms of changes in metabolic activity of microorganisms.

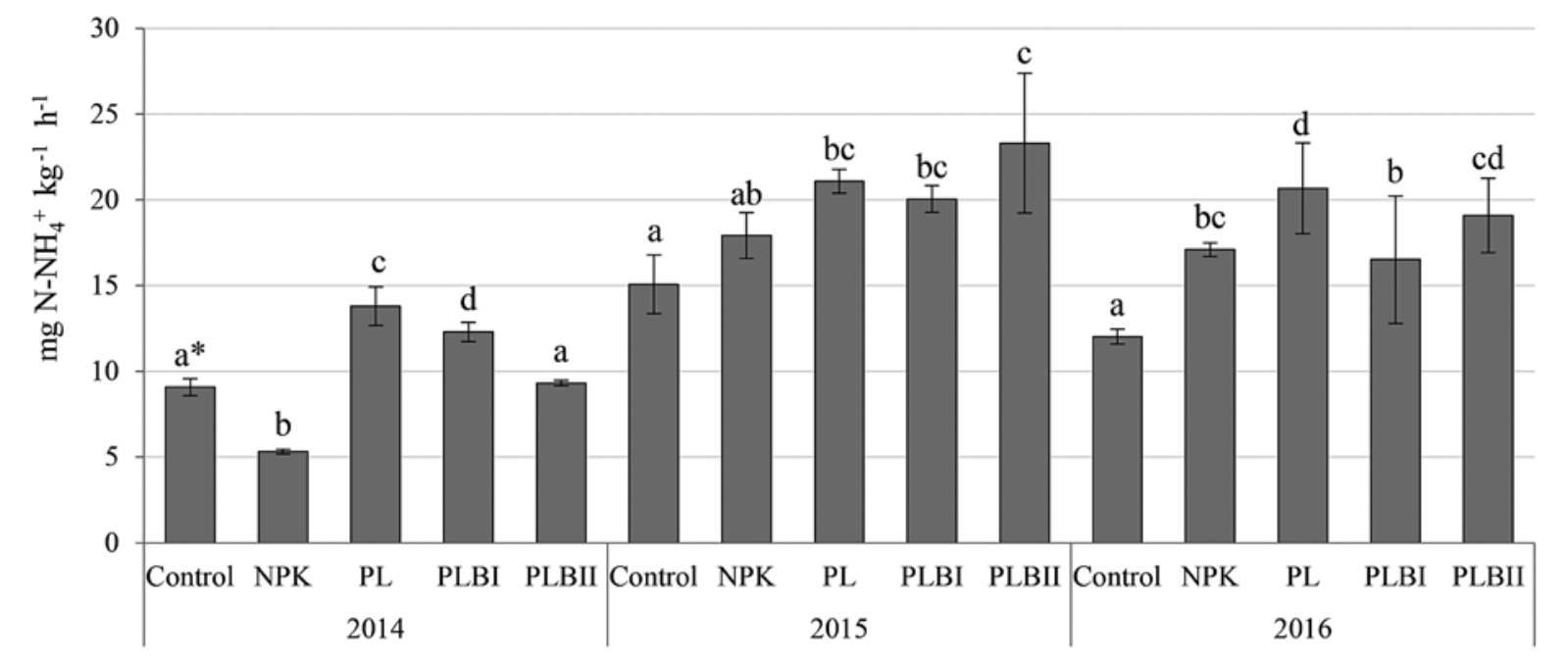

Explanations in and under Table 2; $\mathrm{N}_{-} \mathrm{NH}_{4}^{+}-$ammonium nitrogen

Figure 3. Urease activity of soil in different experimental treatments

Biomass yield. Results of many studies indicated no direct relationship between the total concentrations of potentially toxic elements in biochar and its observable effects on the crop quality (Park et al., 2011; Yang et al., 2015). One of the direct methods illustrating the ecosystems' response to environmental changes is to determine the amount of biomass produced. Soil is a huge reservoir of microorganisms which determine the soil quality and plant productivity. In this study, the lowest yield of perennial grass mixture $\left(21.2 \mathrm{tha}^{-1} \mathrm{DM}\right)$ was obtained in the control treatment, and the highest (30.0 tha ha $\left.^{-1} \mathrm{DM}\right)$ - in the treatment with PL applied (Table 3). The application of biochar at rates of 2.25 and $5 \mathrm{t} \mathrm{ha}^{-1} \mathrm{DM}$ contributed to an increase (in 3-year period) in the amount of grass mixture biomass by $40 \%$ and $31 \%$, respectively, compared to the crop collected from the control. These changes were statistically significant $(p \leq 0.05)$.

Table 3. Biomass yield of perennial grass mixture

\begin{tabular}{ccccc}
\hline \multirow{2}{*}{ Treatment } & \multicolumn{3}{c}{ Year } & \multirow{2}{*}{$\begin{array}{c}\text { The sum of the yield } \\
\text { (3 years) }\end{array}$} \\
\cline { 2 - 4 } & 2014 & 2015 & 2016 & $21.2 \pm 0.73 \mathrm{a}$ \\
Control (without fertilisation) & $7.01 \pm 0.51 \mathrm{a}$ & $6.67 \pm 2.65 \mathrm{a}$ & $7.47 \pm 0.75 \mathrm{a}$ & $24.9 \pm 0.97 \mathrm{ab}$ \\
Mineral fertilisation (NPK) & $9.14 \pm 1.46 \mathrm{ab}$ & $7.23 \pm 1.60 \mathrm{a}$ & $8.57 \pm 1.48 \mathrm{~b}$ & $30.0 \pm 1.55 \mathrm{~b}$ \\
PL & $10.39 \pm 1.79 \mathrm{~b}$ & $11.33 \pm 1.09 \mathrm{~b}$ & $8.30 \pm 0.56 \mathrm{~b}$ & $29.8 \pm 1.32 \mathrm{~b}$ \\
PLBI & $9.30 \pm 2.35 \mathrm{ab}$ & $11.46 \pm 2.72 \mathrm{~b}$ & $9.08 \pm 0.87 \mathrm{~b}$ & $27.6 \pm 0.68 \mathrm{ab}$ \\
PLBII & $9.11 \pm 1.03 \mathrm{ab}$ & $9.90 \pm 2.32 \mathrm{~b}$ & $8.54 \pm 2.14 \mathrm{~b}$ &
\end{tabular}

Explanations under Table 2

Similar results were obtained by Yang et al. (2015), who found that the introduction into the soil of biochars derived from rice straw and corn stalk in rates of $2 \mathrm{t} \mathrm{ha}^{-1}$ increased the yield by $5-15 \%$, while the use of biochar at a rate of $4 \mathrm{tha}^{-1}$ increased the yield by $20 \%$ on average.

\section{Conclusions}

1. The content of analysed heavy metals in forms extracted with $0.01 \mathrm{M} \mathrm{CaCl}_{2}$ depended on the type of organic material introduced into the soil as well as type of element; however, $5 \mathrm{t} \mathrm{ha}^{-1} \mathrm{DM}$ rate of poultry litter biochar was the most effective in the reduction of heavy metal mobility. Poultry litter biochar applied into the soil at rates of 2.25 and $5 \mathrm{tha}^{-1} \mathrm{DM}$ reduced the contents of available forms of cadmium (Cd) by (averaged over 3 years) $24 \%$ and $41 \%$, respectively.

2. Compared to the mineral fertilization (NPK) treatment, significant increase in dehydrogenases activity was observed in the soil with both rates $(2.25$ and $5 \mathrm{tha}^{-1} \mathrm{DM}$ ) of biochar. The organic materials used had no significant effect on urease activity.

3. The application of biochar at rates of 2.25 and $5 \mathrm{t} \mathrm{ha}^{-1} \mathrm{DM}$ significantly increased the biomass yield of 
grass mixture biomass by $20 \%$ and $11 \%$, respectively, compared to the crop collected from the NPK treatment.

4. Coapplication of poultry litter biochar and mineral fertilisers had beneficial effects on soil quality and crop yield.

\section{Acknowledgements}

The research was financed by the Ministry of Science and Higher Education of the Republic of Poland.

Received 26082017

Accepted 05042018

\section{References}

1. Al-Wabel M. I., Al-Omran A., El-Naggar A. H., Nadeem M., Usman A. R. A. 2013. Pyrolysis temperature induced changes in characteristics and chemical composition of biochar produced from conocarpus wastes. Bioresource Technology, 131: 374-379. https://doi.org/10.1016/j.biortech.2012.12.165

2. Bailey V. L., Fansler S. J., Smith J. L., Bolton H. 2011. Reconciling apparent variability in effects of biochar amendment on soil enzyme activities by assay optimization. Soil Biology and Biochemistry, 43: 296-301. https://doi.org/10.1016/j.soilbio.2010.10.014

3. Bayabil H. K., Stoof C. R., Lehmann J. C., Yitaferu B., Steenhuis T. S. 2015. Assessing the potential of biochar and charcoal to improve soil hydraulic properties in the humid Ethiopian Highlands: the Anjeni watershed. Geoderma, 243-244: 115-123.

https://doi.org/10.1016/j.geoderma.2014.12.015

4. Břendová K., Tlustoš P., Száková J. 2015. Biochar immobilizes cadmium and zinc and improves phytoextraction potential of willow plants on extremely contaminated soil. Plant, Soil and Environment, 61 (7): 303-308.

https://doi.org/10.17221/181/2015-PSE

5. Cui L., Yan J., Yang Y., Li L., Quan G., Ding C., Chen T., Fu Q., Chang A. 2013. Influence of biochar on microbial activities of heavy metals contaminated Paddy Fields. Bioresources, 8 (4): 5536-5548. https://doi.org/10.15376/biores.8.4.5536-5548

6. EBC. 2017. European Biochar Certificate. Guidelines for a sustainable production of biochar, version 6.3E. European Biochar Foundation. http://www.european-biochar.org/en

7. Gondek K., Mierzwa-Hersztek M. 2017. The effect of thermal conversion of municipal sewage sludge on the content of $\mathrm{Cu}, \mathrm{Cd}, \mathrm{Pb}$ and $\mathrm{Zn}$ and phytotoxicity of biochars. Journal of Elementology, 22 (2): 427-435. https://doi.org/10.5601/jelem.2016.21.1.1116

8. He Y. D., Zhai Y. B., Li C. T., Yang F., Chen L., Fan X. P., Peng W. F., Fu Z. M. 2010. The fate of $\mathrm{Cu}, \mathrm{Zn}, \mathrm{Pb}$ and $\mathrm{Cd}$ during the pyrolysis of sewage sludge at different temperatures. Environmental Technology, 31 (5): 567-574. https://doi.org/10.1080/09593330903514466

9. Hossain M. K., Strezov V., Chan K. Y., Ziółkowski A., Nelson P. F. 2011. Influence of pyrolysis temperature on production and nutrient properties of wastewater sludge biochar. Journal of Environmental Management, 92 (1): $223-228$ https://doi.org/10.1016/j.jenvman.2010.09.008

10. Houba V. J. G., Temminghoff E. J. M., Gaikhorst G. A., van Vark W. 2000. Soil analysis procedures using $0.01 M$ calcium chloride as extractation reagent. Communications in Soil Science and Plant Analysis, 31 (9-10): 1299-1396. https://doi.org/10.1080/00103620009370514

11. Kloss S., Zehetner F., Dellantonio A., Hamid R., Ottner F., Liedtke V., Schwanninger M., Gerzabek M. H., Sija G. 2012. Characterization of slow pyrolysis biochars: effects of feedstocks and pyrolysis temperature on biochar properties. Journal of Environmental Quality, 41, 4: 990-1000. https://doi.org/10.2134/jeq2011.0070
12. Lehmann J., Joseph S. 2015. Biochar for environmental management: science, technology and implementation ( $2^{\text {nd }}$ ed. $), 944 \mathrm{p}$.

13. Lehmann J., Rillig M. C., Thies J., Masiello C. A., Hockaday W. C., Crowley D. 2011. Biochar effects on soil biota - a review. Soil Biology and Biochemistry, 43: $1812-1836$ https://doi.org/10.1016/j.soilbio.2011.04.022

14. Liu W., Wang S., Lin P., Sun H., Hou J., Zuo Q., Huo R. 2016. Response of $\mathrm{CaCl}_{2}$-extractable heavy metals, polychlorinated biphenyls, and microbial communities to biochar amendment in naturally contaminated soils. Journal of Soils and Sediments, 16: 476-485. https://doi.org/10.1007/s11368-015-1218-z

15. Mierzwa-Hersztek M., Gondek K., Baran A. 2016. Effect of poultry litter biochar on soil enzymatic activity, ecotoxicity and plant growth. Applied Soil Ecology, 105: 144-150. https://doi.org/10.1016/j.apsoil.2016.04.006

16. Mierzwa-Hersztek M., Gondek K., Klimkowicz-Pawlas A., Baran A. 2017. Effect of wheat and miscanthus straw biochars on soil enzymatic activity, ecotoxicity, and plant yield. International Agrophysics, 31: 367-375. https://doi.org/10.1515/intag-2016-0063

17. Oleszczuk N., Castro J. T., da Silva M. M., Korn Md., Welz B., Vale M. G. 2007. Method development for the determination of manganese, cobalt and copper in green coffee comparing direct solid sampling electrothermal atomic absorption spectrometry and inductively coupled plasma optical emission spectrometry. Talanta, 73 (5): 862-869.

https://doi.org/10.1016/j.talanta.2007.05.005

18. Park J. H., Choppala G. K., Bolan N. S., Chung J. W., Chuasavathi T. 2011. Biochar reduces the bioavailability and phytotoxicity of heavy metals. Plant and Soil, 348: 439-451. https://doi.org/10.1007/s11104-011-0948-y

19. Rinklebe J., Shaheen D. M., Frohne T. 2016. Amendment of biochar reduces the release of toxic elements under dynamic redox conditions in a contaminated floodplain soil. Chemosphere, 142: 41-47. https://doi.org/10.1016/j.chemosphere.2015.03.067

20. Song W., Guo M. 2012. Quality variations of poultry litter biochar generated at different pyrolysis temperatures. Journal of Analytical and Applied Pyrolysis, 94: 138-145. https://doi.org/10.1016/j.jaap.2011.11.018

21. Thalmann A. 1968. Zur Methodik der Bestimmung der Dehydrogenase Aktivität im Boden Mittels Triphenyltetrazoliumchlorid (TTC). Landwirtschaftliche Forsch, 21: 249-258 (in German)

22. Wang X., Zhou W., Liang G., Song D., Zhang X. 2015. Characteristics of maize biochar with different pyrolysis temperatures and its effects on organic carbon, nitrogen and enzymatic activities after addition to fluvo-aquic soil. Science of the Total Environment, 538: 137-144. https://doi.org/10.1016/j.scitotenv.2015.08.026

23. Wang Y., Shi J., Lin Q., Chen X., Chen Y. 2007. Heavy metal availability and impact on activity of soil microorganisms along a $\mathrm{Cu} / \mathrm{Zn}$ contamination gradient. Journal of Environmental Sciences, 19: 848-853. https://doi.org/10.1016/S1001-0742(07)60141-7

24. Xu D., Zhao Y., Sun K., Gao B., Wang Z., Jin J., Zhang Z., Wang S., Yan Y., Liu X. 2014. Cadmium adsorption on plant-and manure-derived biochar and biochar-amended sandy soils: impact of bulk and surface properties. Chemosphere, 111: 320-326. https://doi.org/10.1016/j.chemosphere.2014.04.043

25. Xu P., Sun C-X., Ye X-Z., Xiao W-D., Zhang Q., Wang Q. 2016. The effect of biochar and crop straws on heavy metal bioavailability and plant accumulation in a $\mathrm{Cd}$ and $\mathrm{Pb}$ polluted soil. Ecotoxicology and Environmental Safety, 132: 94-100. https://doi.org/10.1016/j.ecoenv.2016.05.031 
26. Yachigo M., Sato S. 2013. Leachability and vegetable absorption of heavy metals from sewage sludge biochar. Hernandez Soriano M. C. (ed.). Soil processes and current trends in quality assessment. InTech, chapter 15 , p. $339-416$.

https://doi.org/10.5772/55123

27. Yang X., Liu J., McGrouther K., Huang H., Lu K., Guo X., He L., Lin X., Che L., Ye Z., Wang H. 2016. Effect of biochar on the extractability of heavy metals $(\mathrm{Cd}, \mathrm{Cu}, \mathrm{Pb}$, and $\mathrm{Zn}$ ) and enzyme activity in soil. Environmental Science and Pollution Research, 23: 974-984. https://doi.org/10.1007/s11356-015-4233-0

28. Yang Y., Ma S., Zhao Y., Jing M., Xu M., Chen J. 2015. A field experiment on enhancement of crop yield by rice straw and corn stalk-derived biochar in Northern China. Sustainability, 7: 13713-13725. https://doi.org/10.3390/su71013713

29. Yavari S., Malakahmad A., Sapari N. B. 2015. Biochar efficiency in pesticides sorption as a function of production variables - a review. Environmental Science and Pollution Research, 22: 13824-13841.

https://doi.org/10.1007/s11356-015-5114-2

30. Zantua M. I., Bremner J. M. 1975. Comparison of methods of assaying urease activity in soils. Soil Biology and Biochemistry, 7: 291-295.

https://doi.org/10.1016/0038-0717(75)90069-3

31. Zheng R., Chen Z., Cai C., Tei B., Liu X., Reid B. J., Huang Q., Lei M., Sun G., Baltrenaite E. 2015. Mitigating heavy metal accumulation into rice (Oryza sativa L.) using biochar amendment - a field experiment in Hunan, China. Environmental Science and Pollution Research, 22: 11097-11108. https://doi.org/10.1007/s11356-015-4268-2

32. Zhu L., Xiao Q., Cheng H., Shi B., Shen Y., Li S. 2017. Seasonal dynamics of soil microbial activity after biochar addition in a dryland maize field in North-Western China. Ecological Engineering, 104: 141-149. https://doi.org/10.1016/j.ecoleng.2017.04.026

ISSN 1392-3196 / e-ISSN 2335-8947

Zemdirbyste-Agriculture, vol. 105, No. 3 (2018), p. 203-210

DOI $10.13080 /$ z-a.2018.105.026

\title{
Naminių paukščių kraiko bioanglies ir mineralinių trąšų derinio ịtaka dirvožemio kokybei ir augalų derliui
}

\author{
M. Mierzwa-Hersztek ${ }^{1}$, K. Gondek ${ }^{1}$, A. Klimkowicz-Pawlas ${ }^{2}$, M. Kopeć ${ }^{1}$, T. Lošák ${ }^{3}$ \\ ${ }^{1}$ Krokuvos žemès ūkio universitetas, Lenkija \\ ${ }^{2}$ Pulavų valstybinis dirvožemio mokslo ir augalininkystès mokslinių tyrimų institutas, Lenkija \\ ${ }^{3}$ Mendelio universitetas Brno, Čekija
}

\section{Santrauka}

Tyrimo metu vertinta naminių paukščių kraiko bioanglies įtaka dirvožemio kokybei ir ganyklinių žolių mišinio derliui. Mažų laukelių lauko eksperimentas pasotintajame rudžemyje buvo įrengtas penkiais variantais: 1) netręšta (kontrolinis), 2) tręšta mineralinėmis NPK trąšomis, 3) NPK + naminių paukščiu kraikas 5 t ha $\left.^{-1} \mathrm{SM}, 4\right) \mathrm{NPK}+$ bioanglis 2,25 $\mathrm{t} \mathrm{ha}^{-1} \mathrm{SM}$ ir 5) NPK + paukščiu kraiko bioanglis $5 \mathrm{t} \mathrm{ha}^{-1} \mathrm{SM}$. Siekiant sukurti panašias sąlygas, buvo tręšta tokiomis normomis mineralinių trąšų: $100 \mathrm{~kg} \mathrm{ha}^{-1} \mathrm{~N}, 40 \mathrm{~kg} \mathrm{ha}^{-1} \mathrm{P}$ ir $120 \mathrm{~kg} \mathrm{ha}^{-1} \mathrm{~K}$. Siekiant nustatyti dirvožemio biologinių ir cheminių savybių pokyčius, 2014-2016 m. analizuoti èminiai. Ganyklos biomasès metinė produkcija buvo nustatyta tris kartus per metus nuėmus derlių. Siekiant apibūdinti dirvožemio biologines savybes, nustatytas dirvožemio fermentų dehidrogenazès ir ureazès aktyvumas.

Tyrimo rezultatai parodè, kad tręšimas NPK trąšomis kartu su 2,25 arba $5 \mathrm{t} \mathrm{ha}^{-1} \mathrm{SM}$ bioanglies sumažino judriųu formų kadmio $(\mathrm{Cd})$, švino $(\mathrm{Pb})$ ir cinko $(\mathrm{Zn})$ kiekius dirvožemyje. Reikšmingas dehidrogenazės aktyvumo padidèjimas nustatytas dirvožemyje, tręštame abiem normomis paukščių kraiko bioanglies. Toks tręšimas taip pat padidino ganyklinių žolių mišinio produkciją (trejų metų derlių sumą), palyginus su tręšimo NPK trąšomis variantu.

Reikšminiai žodžiai: bioanglis, biomasės derlius, fermentų aktyvumas, lauko bandymas, sunkieji metalai, ureazès aktyvumas. 